\title{
Charisma and Democracy: Max Weber on the Riddle of Political Change in Modern Societies
}

\author{
Pedro T. Magalhães ${ }^{1,2}$ (1)
}

Accepted: 4 September 2021 / Published online: 11 October 2021

(c) The Author(s) 2021

\begin{abstract}
The elite theory of Max Weber has recently been rediscovered by political scientists and political theorists who have sought to explore both the heuristic and the normative potential of plebiscitary leader democracy. Notwithstanding the merits of this wave of studies, this paper argues that attention should be shifted from Weber's context-specific defence of plebiscitary leadership in post-WWI Germany to his broader conception of charisma as an attempt to grasp the enigma of significant social and political change. Contemporary democratic theory, this paper contends, can fruitfully draw on Weber to sink into the antinomies and ambiguities of a transformative democratic politics.
\end{abstract}

Keywords Charisma $\cdot$ Democracy $\cdot$ Indeterminacy $\cdot$ Plebiscitary leadership $\cdot$ Revolution $\cdot$ Weber

\section{Introduction}

Elite theory occupies a rather ambivalent position in political studies. On the one hand, the sociological study of political elites and ruling groups stretches back to the founding generations of modern social science in the late nineteenth century. The fact that the sub-discipline of elite studies can claim a very direct link with some of the modern classics of social science, such as Vilfredo Pareto and Max Weber, has thus given it an enduring position of prestige within mainstream empirical political science. On the other hand, however, the normative implications of the elitist perspective have been relentlessly criticized by democratic theorists. Indeed, political theorists and historians of political thought from diverse backgrounds have frequently raised concerns regarding the problematic origins and connotations of competitive elitism as amodel of democracy, and their enduring, often unacknowledged influence on empirical research (Nye 1977, Held 2006: ch. 5, Mackie 2009, Scheuerman 2020: ch. 7). ${ }^{1}$

Pedro T. Magalhães

pedro.t.magalhaes@eeg.uminho.pt

1 University of Helsinki, Siltavuorenpenger 1A, 00014 Helsinki, Finland

2 University of Minho, School of Economics and Management, Campus de Gualtar, 4710-057 Braga, Portugal
Such a state of affairs, marked by a rigid division of labour - and lack of any fruitful dialogue - between empirical political science and normative political theory, has been challenged by recent developments in both fields. In political theory, Jeffrey E. Green's The Eyes of the People develops an ocular-as opposed to vocal-model of democracy, based on the ideal of candour, which seeks to spell out 'the great unelaborated ethical commitment of plebiscitary democracy' (Green 2010a: 130). Despite most elite theorists' own claims to the contrary, Green submits that competitive elitism is not merely a realist account of how modern mass democracies work, but is also a normative theory of democracy, whose moral dimension and progressive potential he seeks to unfold. In political science, András Körösényi and his associates have taken the bold step of defending leader democracy not only on the grounds of its greater realism compared to classical models of democracy, but also emphasizing its normative elements (Pakulski and Körösényi 2012). Although, 'as an explanatory-analytical model,' competitive elitism 'does not need any normative justification,' it does have a strong normative dimension in that it seeks to ensure 'the accountability and responsibility

\footnotetext{
${ }^{1}$ A first version of this article was presented in October 2020 at the EUROSTORIE research seminar in Helsinki. I am grateful to all the participants there for their comments and suggestions. Furthermore, I am thankful to this journal's anonymous assessor for her insightful criticism on a previous draft. Finally, I would also like to thank Mark Shackleton for the language revision.
} 
of leaders,' to produce 'a responsible government' (Körösényi 2005: 378).

These new developments have of course meant a rediscovery and reengagement with the work of the intellectual pioneers of the competitive elitist model of democracy, namely Max Weber and Joseph Schumpeter. ${ }^{2}$ On the whole, it seems fair to conclude that the most promising insights of this reconsideration of the normative import of competitive elitism have been drawn from the former. Indeed, although Green (2010b) does provide a qualified defense of Schumpeter in reply to the criticism levelled against the AustroAmerican economist by contemporary political theorists, it is above all from Weber that he draws upon for his ocular reinterpretation of popular rule (Green 2010a: ch. 5). Moreover, while Körösényi's $(2005,2009)$ earlier conception of leader democracy is essentially Schumpeterian, in his latest writings Weber has emerged distinctly as the stronger influence (Körösényi 2019; Körösényi et al. 2020). ${ }^{3}$

This article joins the recent wave of theoretically informed studies on elites and democracy in emphasizing the relevance of Weber for contemporary democratic thought. However, in contrast to the main thrust of the literature, I propose a change of focus from Weber's quite specific and context-dependent defence of leader democracy (Führerdemokratie) in post-WWI Germany to his broader concept of charisma. To be sure, both Green and Körösényi do not fail to point out the crucial role played by charismatic authority in their theories of plebiscitary/leader democracy. Nevertheless, they subordinate the former concept to the latter, treating charisma as a specification of the type of leadership implied in their visions of democracy.

The problem with this approach, in my view, is not so much the violence it does to the original-which it undoubtedly does, since Weber wrote much more extensively on charisma than he did on plebiscitary leadership, treating the latter merely as one possible incarnation of charismatic authority under modern conditions (though, to be sure, he focused on it in his later political writings). Rather, what this fixation on plebiscitary leadership has regrettably pushed into the background is the ineradicable, and yet intrinsically tensional, link between charisma and the prospect of a transformative democratic politics. The enigma of large-scale

\footnotetext{
2 On the similarities and differences between Weber's and Schumpeter's approaches to the problem of modern democracy, see Magalhães (2021: 179-184).

3 The turn from Schumpeter to Weber in this scholar's work has been accompanied by 'a more pessimistic account' of the normative import of leader democracy (Körösényi 2019: 284). This is not surprising, and although the political developments in Hungary since 2010, which Körösényi has been studying in depth, might have contributed to the pessimism, there are theoretical reasons behind it as well, stemming from the intrinsic ambivalence of the Weberian outlook.
}

social and political change, rather than a concern with the stability of political formations, is at the heart of Weber's œuvre, and this is what should attract democratic theorists to the German thinker. For while the appeal to (plebiscitary) leadership is more often than not a symptom of the crises it purports to solve (see Scott 2018), the broader question of the role of personal authority in igniting significant political change remains a challenge for democratic theory. Reading Weber with a focus on the concept of charisma, I argue, confronts us with a fundamental paradox: democracy, in order to sustain the promise of meaningful political change, has to rely on the force of personal authority, a force that easily turns into democracy's own enemy.

This essay is structured in three parts. First, my analysis concentrates on Weber's concept of charisma, bringing to the fore not only its pivotal role in his sociology of domination, but also the transformative vision of politics that it connotes (2.). Subsequently, I turn to the tension between charisma as a personal type of authority and impersonal, rational legality as the predominant source of legitimacy in modern societies, specifying how, for Weber, the question of democracy is involved in this larger historico-philosophical tension (3.). While Weber himself, in the critical juncture of post-imperial Germany (1919-1920), may very well have failed to elaborate a democratic reading of charisma that does justice to a transformational understanding of politics, one should not take the episodic defense of plebiscitary leadership as his definitive word on the topic, or as the crystallization of his broader vision. Indeed, the very force of his philosophico-sociological insight compels us to look beyond the strict bounds of plebiscitary leadership within which Weber confined himself at the dawn of the Weimar Republic — and towards the end of his life. Thus, in the final section, I step beyond the controversies regarding plebiscitary leadership to indicate a different, novel sense in which Weber's conception of charisma might fruitfully be read by contemporary democratic theorists (4.).

\section{Weber's Concept of Charisma}

The word "charisma," which made its way into modern European languages via ecclesiastical Latin from the Greek, is nowadays widely used. Most often, it refers loosely to the attractiveness and magnetism that certain personalities seem to be graced with-to ineffable personal qualities which a few possess in contrast to the many, attracting not just attention, but also fascination and devotion to their persons. Even a very superficial analysis of ordinary language use would allow us to conclude that there must be many different types of charisma, or alternatively, that the term is used to label rather diverse phenomena. Although, say, both Michael Jackson and Charles de Gaulle have been termed 
charismatic, it is evident that they are so in different senses. That much is certain, even if one may still find it hard to spell out what makes these two personalities charismatic in their own way.

When Max Weber, in the 1910s, selected the term to designate one of the three pure types of legitimate rulealongside tradition and rational legality-its usage was not very common. Indeed, one can speculate that the later resonance of Weber's triad of ideal types may have contributed to the popularization of the notion, by supplying it with a broader meaning than that which it possessed in the theological discussions of the late nineteenth century. The main direct source of Weber's idea of charisma is Rudolph Sohm's (1892) historical interpretation of canon law. Sohm, whose lectures Weber attended in Strasbourg, meant by charisma the ineffable divine grace conferred upon the early Christian community, as opposed to the later legalistic and bureaucratic development of the Roman Church. Weber's sociological imagination, in turn, took the concept beyond the confines of Christian theology and church history, giving it a prominent place in his sociology of domination.

In Politik als Beruf, the famous lecture Weber delivered to students in Munich amidst the revolutionary turmoil of 1919, the author sketches at the outset the three ideal types of legitimate rule he had been working on for about a decade. These ideal types indicate different bases for what he elsewhere refers to as 'the belief in legitimacy' (Legitimitätsglaube), which explains the voluntary submission of the ruled to the extant patterns of domination (Weber 1978: 213). Two of them seem to rest on a natural tendency to conform to what the status quo prescribes: Traditional authority derives its appeal from the 'habitual predisposition to preserve' what has always been, while rational legality rests 'on a predisposition to fulfil one's statutory obligations obediently' (Weber 1994: 311-312). Charisma, by contrast, connects rulers and ruled more personally based on the 'trust' and on the 'devotion' of the latter to the extraordinary qualities of the former. Charisma, in other words, 'is the authority of the exceptional' (Weber 1994: 312). It is hardly surprising, thus, that in a lecture on politics as a calling/vocation/ profession-depending on how one chooses to translate the polysemic German word Beruf-the focus falls precisely upon this type of authority. Because charisma is the only intrinsically personal type of authority, then surely 'this is where the idea of vocation (Beruf) in its highest form has its roots' (Weber 1994: 312). ${ }^{4}$ However, charisma is not only essential to understand politics as a personal calling. More than that, for Weber, charisma emerges as the one distinctively political form of authority.

\footnotetext{
${ }^{4}$ Emphasis in the original.
}

As Palonen (2002: 34-35) keenly argues, Weber's understanding of politics as striving and struggle is fundamentally oriented towards transformation. Efforts to preserve power and maintain the status quo are, according to this view, only derivatively political, inasmuch as they must first be activated by the striving of those who wish to alter the existing patterns of domination. Among the Weberian ideal types, charisma appears as the only form of authority that ties in with such a transformative vision. In contrast to such a vision, when Weber's focus drifts to the analysis and explanation of consolidated patterns of social interaction, of 'generalized uniformities of empirical process' (Weber 1978: 19), tradition and rational legality become more relevant as ideal types of legitimate domination. Unsurprisingly, thus, charisma is referred to only in passing, as an exception to tradition and rational legality, in the conceptual introduction to Economy and Society, where Weber's sociological approach appears to be moving in a more empiricistpositivist direction (Weber 1978: 37-38).

Of course, the logical relations between the pure types of legitimate rule, as well as the historical relations between their empirical variants, remain a much-debated issue. As the main conceptual and methodological tools of Weberian sociology, the ideal types are trans-historical, time-travelling categories that evince descriptive and/or explanatory potential in various contexts. However, from a broader worldhistorical perspective, there is a developmental trend travelling through them. The retrospective approach adopted in the exposition of the sociology of domination constitutes a clear proof of this: Weber (1978: 213) begins by looking at rational legality (the ideal type) and bureaucracy (the historical variant), because 'it is best to start from modern and therefore more familiar examples' and then move to the historically older types and forms. In another context, he posits that 'tradition is the oldest and most universal type of legitimacy' (Weber 1978: 37), and from a historical perspective, such a statement can indeed hardly be denied. However, from a logical viewpoint, the priority of tradition relative to charisma is impossible to determine, as the issue would inevitably lead us to a chicken-or-the-egg type of causality dilemma. ${ }^{5}$ One thing is certain, though: rational legality comes last, and its rise, manifested in the development and spread of bureaucratic forms of rule, is the crucial modern phenomenon that begs for an explanation. In light of the overarching developmental trend that travels through the ideal types, it is therefore advisable not to treat them on

\footnotetext{
${ }^{5}$ For every instance of traditional rule can in principle be brought back to a charismatic origin (a victorious war leader, a communityfounding religious prophet, etc.), while every transformative charismatic movement asserts itself necessarily against some pre-existing, consolidated form of rule.
} 
a formally equal footing, but rather to distinguish sharply between durable and ephemeral, or ordinary and extraordinary, forms of rule, i.e. between tradition and rational legality on the one hand, and charisma on the other.

In essence, the development Weber wishes to elucidate, and which he views as a Western singularity, is that which leads from tradition to rational legality, that is, from one stable, ordinary form of domination to another, entirely new one (Schluchter 1981: 106-121). One might think, according to such a Western world-historical perspective, that the relevance of charisma recedes. Indeed, whether the eruptions of charismatic authority contribute to the grand transition to rational-legal domination or, on the contrary, lash back at it, one would be tempted to assume that because of their ephemeral nature they have little historical significance. But that would be too hasty a conclusion. For the developmental trend which takes us from pre-modern traditional domination to modern rational rule is, according to Weber, not driven by an immanent impulse. Stable rule and ordinary life, both in their traditional and modern rational variants, tend, in Weber's view, towards immobility and petrification. To be sure, the rise of rationalism has profoundly changed Western humankind. Nonetheless, at the end of such a 'tremendous development,' as the climax of The Protestant Ethic presages, the West faces yet again the grim prospect of cultural and political petrification (Weber 1992: 124). According to Weber, hence, there is only one interruptive force in history which, however transiently, can break through the inertia of both pre-modern and modern everydayness. That force is what he calls charisma:

[C]harisma, in its most potent forms, disrupts rational rule as well as tradition altogether and overturns all notions of sanctity. Instead of reverence for customs that are ancient and hence sacred, it enforces the inner subjection to the unprecedented and absolutely unique and therefore Divine. In this purely empirical and value-free sense charisma is indeed the specifically creative revolutionary force of history. (Weber 1978: 1117)

Thus, despite its precarious and transient nature, charisma seems to contain the key to the problem of domination. The powers of the ordinary and the everyday can only be grasped, if one is able to discern how they tame the disruptive impact of charisma. The nature and features of any consolidated pattern of domination, be it of a traditional or rational-legal kind, become fully understandable only as instances of the inevitable transformation of charismatic disruptions of rule, of their (re)conversion to the predictability and rigidity of everyday practices. Therefore, Weberian concepts such as 'hereditary charisma' or 'charisma of office' - and more generally the idea of a 'routinization of charisma' - where charisma meets either tradition or rational legality, not only constitute mixed forms, which stand analytically in-between the abstraction of the ideal type and the messiness of empirical reality. In addition, they also convey a derivation from a focal, ebullient point of domination that renders lasting, ordinary forms of rule intelligible in the first place (Weber 1978: 246ff., 1121ff.). ${ }^{6}$

Eventually, and by necessity, charisma 'gives way to the forces of everyday routine' (Weber 1978: 252). However, the two great historical forces of routinization-tradition and rational legality - stand not only in sharp analytic contrast to each other, but also in broad world-historical succession to one another. Despite the many pages Weber dedicates to the analysis of traditional forms of domination, from the primordial variants of patrimonial rule one encounters in virtually all civilizational contexts to European feudalism more specifically, the puzzle that truly captivates him is that of the rise of rational rule and its ambivalent effects. Indeed, the very analysis of traditional forms of domination is largely oriented towards the embryonic signs of rationalization they contain.

In this regard, it is important to emphasize that Weber's understanding of rationalization as a process has little to do with the progressive idea of reason as it was conceived-and worshiped-by Enlightenment philosophy. Weber's story of Western rationalization is not a tale of moral progress. According to him, indeed, one should refrain from indulging in 'the infinitely naïve, childish belief in the power of reason' (Weber 2008: 104). ${ }^{7}$ Anyone familiar with his sociology knows only too well, however, that the power of the rational can hardly be overestimated. In fact, it seems to be both ubiquitous and inexhaustible. What rationalization does to charisma is roughly this: charismatic movements, be they religious and/or political, in their struggle against the status $q u o$, seek the support of as many followers as possible. To enlarge their social bases, their doctrines, which originally rested on 'the inner subjection to the unprecedented and absolutely unique,' are reformulated in ever-more abstract, universally appealing terms, in order to overcome class and status barriers. Once the movement triumphs, in the specific sense that its ethos becomes that of the community as a whole - and as a sign of that triumph-domination crystallizes into fixed, regular practices that thus put an end to the fleeting instant of charismatic disruption (Weber 1978: 1180).

The contrast between substantive or value-rationality, on the one hand, and formal or instrumental rationality, on

\footnotetext{
${ }^{6}$ On the pivotal role of charisma in Weber's sociology of domination, see Mommsen (1974a: 128) and Hanke (2001: 32).

7 This remark from a 1915 letter to Mina Tobler occurs in the context of a discussion of Plato. All translations from German sources are my own.
} 
the other, is usually invoked to explain Weber's concept of rationalization, the idea being that the latter involves an increasing emphasis on form and instrumentality to the detriment of substance. While this surely identifies a general trend of Western rationalization, one must nevertheless note that considerations of substance and value are ineradicable, even by the most thoroughly developed systems of rationallegal domination. Furthermore, I do not think that the idea of instrumentality, with its focus on the adequacy between means and ends, penetrates to the core of Weber's concept of rationalization. Instead, I would suggest an emphasis on the notion of routine, for what is ultimately at stake pertains to the emergence of methods and techniques which in and by themselves, irrespective of their orientation towards either unconditional values or strategic goals, bring order to human life. For Weber, as one commentator suggests via an interesting analogy to the psychoanalysis of Ernest Jones, rationalization qua routinization appears to be a universal phenomenon, present to some extent in every instance of meaningful social interaction, "even in the magic rites of supposedly "primitive peoples" (Radkau 2013: 544). Notwithstanding such universality, however, it is in the modern "Occident" that rationalization seems to have reached a degree of intensity as never before in human history.

\section{Charisma, Bureaucracy and Democracy}

The intensity of modern Western rationalization is illustrated by the quintessential historical configuration of rational-legal domination, namely bureaucracy. Weber equated the transformations of tradition and charisma into modern rational domination with the expansion of bureaucratic administration, and so much so that he uses the adjectives "rational," "legal," and "bureaucratic" almost interchangeably (Schluchter 1981: 109). While, for Marx, the crux of capitalism resided in the separation of the worker from the ownership of the means of production, for Weber, the hallmark of the modern age is instead the separation of the administrative staff from the ownership of the means of administration, these means becoming the property of large-scale organizations (Weber 1978: 980ff.). ${ }^{8}$ '[W]ithout regard to the person' is the guiding principle of bureaucratic rule, which, in contrast to traditional types of domination, is bounded by formal hierarchies and written statutes rather than personal loyalties or precedent (Weber 1978: 600). Much like his vision of modernity in general, Weber's verdict on bureaucracy is also markedly ambivalent, punctuated by a blend of fascination and horror (Mommsen 1989: 109-120). He is fascinated by its 'technical superiority over

${ }^{8}$ On Weber and Marx, see Mommsen (1977). any other form of organization' and the immense material possibilities thus opened up for modern societies, as well as for its breakdown of the "[a]uthoritarian powers resting on personal loyalty, such as theocracy and patrimonial monarchy' (Weber 1978: 811, 973). ${ }^{9}$ Yet fascination goes hand in hand with anxiety, for bureaucratic administration might not just accomplish, as it usually does with unmatched efficiency, the routinization of charisma, but also its 'castration' (Weber 1978: 1137), and therewith we witness the foreclosure of cultural and political innovation, and the dawn of an era of 'mechanized petrification' (Weber 1992: 124).

In the final analysis, bureaucratic domination is the by-product of a rationalism that has 'consistently worked through to the disenchantment of the world and its transformation into a causal mechanism' (Weber 1946: 350). Bureaucratic domination rests on the assumption, as Weber (1946: 139) puts it in Wissenschaft als Beruf, 'that one can, in principle, master all things by calculation.' To inhabit this disenchanted world epitomized by bureaucracy means, thus, to live not just in a 'godless,' but also in a 'prophetless time' (Weber 1946: 153), impervious to charisma as the 'specifically creative revolutionary force of history.' As Peukert (1989: 12-15) rightly notes, this dual characterization of the modern age acknowledges Nietzsche's diagnosis, yet at the same time repudiates the consequences that the philosopher extracted from it. For Nietzsche remained stuck in a reactive, exalted form of prophesizing, which from Weber's viewpoint was both scholarly and politically irresponsible. '[A]rmchair prophecy' was but an illusory promise of re-enchantment, an escapist 'ersatz' (Weber 1946: 153). Contrary to what cultural critics inspired by Nietzsche fantasized about, Weber maintained soberly that there is no escape from the disenchanted world in which modern Western humankind must live, which also means no escape from bureaucratic domination. The question was rather whether there was still room for cultural and political innovation, despite the ineluctability of bureaucratic rule and its inherent petrifying tendencies.

To answer that question one must clarify how, in Weber's conceptual structures and political analyses, the problem of democracy relates to the grander narrative of rationalization. Historically, Weber traces democratic movements and ideas back to the forms of 'non-legitimate domination' that have emerged in ancient and medieval Western cities. According to him, the emergence of cities, qua political entities, with a claim to autonomy vis-à-vis traditionally legitimated patrimonial domination is another Western singularity. Western cities constituted the historical scene of revolution or usurpation as forms of resistance to traditional rule. In that sense, 'non-legitimate domination' is not a fourth ideal type,

\footnotetext{
${ }_{9}$ Emphasis in the citations omitted.
} 
equally capable of trans-historical travelling, but rather an abstract, idealized explanation of comparable phenomena occurring in a relatively precise historical configuration and, to a significant extent, peculiar to that configuration. From a more general viewpoint, of course, such episodes where patterns of rule legitimated by tradition are abruptly disrupted would fall under the ideal-typical category of charisma. Through the concept of 'non-legitimate domination,' however, in contrast to the three ideal types of legitimacywhere the claims of rulers and their acceptance take centre stage-Weber shifts the perspective to the ruled and their capacity to challenge a ruler's traditional legitimacy by coming together as demos, plebs, popolo, comune, and so on. These revolutionary or usurpatory dynamics, whose success appears to be historically restricted to urban settings in the West, are the sources of democratic politics (Weber 1978: 1212ff. and esp. 1301ff.).

However, in contrast to ancient and medieval democratic phenomena, modern democracy emerges as a territorial nation-state. This larger spatial and demographic dimension requires, from the viewpoint of administration, the most developed rational-legal forms of rule. Although these aim primarily at administrative efficiency, they also correlate in important respects with a democratic ethos. For instance, formal equality before the law and the abolition of feudal privileges and hierarchies are in equal measure triumphs of modern rational-legal administration and democracy. One could therefore say that while the revolutionary appeal to the people is taken over from ancient and medieval incarnations, which were generally unstable and quite ephemeral, democracy in a modern nation-state depends, for effectiveness and stability, on the mechanisms of rational-legal administration, which give modern democracy a peculiar colouring.

In a posthumously published essay on 'The Three Pure Types of Legitimate Domination,' Weber treats modern democracy explicitly as a variety of charismatic authority. More specifically, he conceives it as an anti-authoritarian reinterpretation of charisma. This reinterpretation entails a reversion of the original causal nexus: the authority of the charismatic leader no longer stems from intrinsic exceptional qualities, which per se command the devotion of followers-in the pure form of charismatic authority, obedience, far from being a matter of choice, is owed to the ruler that proves to be touched by grace - but rather from the selection of the leader by the followers. Indeed, modern democracy turns 'the free recognition [of the ruler] by the ruled' into 'the prerequisite of legitimacy and its basis' (Weber 2005: 741-742). Yet in doing so, modern democracy also threatens to transform political leaders into mandataries of the ruled, and ultimately into bureaucrats entrusted with the task of carrying out the will of those who elect them. Weber concludes the essay by noting that the difference between an elected leader (Führer) and an elected official (Beamte) lies then solely on the meaning that the person attaches to the political office and conveys both to direct subordinates and to the voters: "Natural-born" leaders will act according to their own judgement and feel personally responsible for the consequences of their actions, while bureaucrats "by nature" will perceive themselves to be acting under the instructions of their electors, without a sense of personal commitment and responsibility (Weber 2005: 742).

For Weber, hence, the crucial question in matters of constitutional design - matters that he was deeply involved in, especially in the aftermath of WWI-was which type of personality would the design of political institutions attract and select. The Bismarckian experience of an impotent parliament vis-à-vis the imperial government and its bureaucracy led Weber to believe that only a powerful, self-confident parliament could put a check on bureaucratic rule. His vision of a strong parliamentary system was shaped by the need to counter the 'all-powerful trend towards bureaucratisation' (Weber 1994: 159). This made him see past the typical—in his own words, 'negative' and 'antiquated'-liberal priorities concerning the assurance of spheres of freedom from governmental intervention (Weber 1994: 159). What made the spectre of bureaucratization so frightening in Weber's eyes was not so much the menace it harboured for individual rights and liberties - though these, to be sure, were also at stake-but rather the dark promise of an era of political petrification where rational-legal forms of rule would become impervious to change. Among the "remnants of "individual" freedom' Weber (1994: 159) wished to rescue from the inexorable progress of bureaucracy ranked, foremost, a measure of creative freedom for the political leader, which alone could catalyse change and innovation.

The Weberian yardstick to measure the merits of parliamentary government was therefore its capacity to promote the selection of talented political leaders, who would nurture and refine in parliament their intrinsic charismatic qualities. However, the specific conditions of mass politics, after the establishment of universal suffrage and the rise of large-scale party organizations, brought major challenges to this view of parliamentarism. Indeed, would not the parliamentary elites tend to develop rigid links with the already highly bureaucratized, or rapidly bureaucratizing, party organizations that dominate mass electoral politics, thus succumbing to the much-feared 'all-powerful trend'? Structurally, as Robert Michels's (1911) influential study on the German Social-Democratic party had shown-and Weber agreed - the internal development of political parties differed little from the unstoppable evolution of state administration and industrial capitalism in a bureaucratic direction. In a passage from Economy and Society where echoes from Michels's book can clearly be heard, Weber 
(1978: 951) notes that a modern political party 'tends toward a strict hierarchical structure, however carefully it may be trying to hide this fact. ${ }^{10}$

Weber's disenchanted vision of modern life in general, and modern politics in particular, made him come to terms with the paradoxical elitist trade-off of mass politicsnamely, that strict organizational hierarchy is the price to be paid for the inclusion of the hitherto excluded masses in the political sphere-more easily than his friend and protégé Michels. To Weber, the contraction at the higher echelons of the political class came as no surprise and without a hint of exasperation, for, as he saw it, the historical successes of democracy had always been achieved at the cost of concessions to a Caesaristic principle of leadership (Weber 1994: 174). What frightened him was rather the possibility that "true" political leadership, in its capacity to trigger broader social and cultural change, might vanish under the mounting pressure of bureaucracy.

In the traumatic first steps of the Weimar Republicamidst a revolutionary turmoil where more immediate concerns besides an abstract fear of bureaucracy played a major role-Weber's constitutional design proposals acquired increasingly plebiscitarian contours. While parliaments everywhere in Europe had been at the forefront of the achievement of civic rights and liberties, now was the time 'to recognise the Magna Charta of democracy, the right to the direct election of the leader' (Weber 1994: 308). The president of the Reich, rather than parliamentary party leaders, thus emerged as the institutional guarantee of democratic political leadership:

A popularly elected president, as the head of the executive, of official patronage, and as the possessor of a delaying veto and the power to dissolve parliament and to consult the people, is the palladium of genuine democracy, which does not mean impotent self-abandonment to cliques but subordination to leaders one has chosen for oneself. (Weber 1994: 308)

Weber was very much aware of the implications of this plebiscitarian reading of modern democracy in terms of the rift that, under the guise of an apparently closer, unmediated relationship, opens up between leaders and followers, between the top and the bottom of the political system. To remain at the disposal of the leader as 'a useful apparatus,' Weber (1994: 351) writes in Politik als Beruf, 'the following has to obey blindly' and undergo a process of 'spiritual proletarianisation.' For 'the only choice' there is 'lies between a leadership democracy with a "machine" and... rule by the "professional politician" who has no vocation, the type of

${ }^{10}$ On Weber and Michels, see Scaff (1981) and Mommsen (1989: 87-105). man who lacks precisely those inner, charismatic qualities which make a leader' (Weber 1994: 351). ${ }^{11}$

Weber died in June 1920. Thus, his defence of an eminently plebiscitary design for German democracy, summarized in the February 1919 newspaper article on 'The President of the Reich' (Weber 1994: 304-308), stands chronologically as his last word on the topic. This coincidence, however, should not let us forget that such a defence, far from constituting the logical culmination of his thinking on charisma and democracy, was rather episodic and motivated by the very specific political context of postWWI Germany. Weber's focus shifted quite suddenly from the institution of parliament to that of the president as the cornerstone of democracy in the early days of the Weimar Republic, and it is hard to speculate how his political analysis would have evolved if he had lived longer.

To be sure, Weber's plebiscitary-presidentialist turn deserves most of the criticism it has received. It seems, indeed, that Weber was too mesmerized by the spectre of bureaucracy and the petrification of rational-legal rule to foresee the peril, lurking just around the corner, of a neoauthoritarian reinterpretation of charisma. Mommsen (1974b: 435-437), his first critic in that regard, may have been too harsh in accusing Weber of having unwittingly paved the way to the rise of totalitarian dictatorship in Germany. However, he was essentially correct in drawing attention to the conspicuous homology between Weber's vision of a presidential leader democracy and Carl Schmitt's theory of the plebiscitary legitimacy of the Reichspräsident, developed during Weimar's final regime crisis (Mommsen 1974b: 408-413). ${ }^{12}$ More recently, and from a perspective closer to our own, Kalyvas (2008: 77) has argued that 'Weber's theory of the plebiscitarian president' ends up disavowing the transformative dimension of charismatic politics and 'ultimately amounts to the de-charismatization of charisma. ${ }^{13}$ In fact, in his later political journalism, Weber becomes predominantly concerned with the survival of liberal democracy and the capitalist economic order, relegating to the background the enigma of comprehensive social and political innovation that featured at the core of his earlier, more theoretical writings on charisma. Weber, the political journalist, writes

\footnotetext{
11 The English translation here cannot convey the wit of the German pun-Berufspolitiker ohne Beruf-which plays with the double meaning of the word Beruf.

${ }^{12}$ Later on, Mommsen (1984: vii) would concede that his indictment of Weber rested on a rather 'fundamentalist conception of democracy, which emphasized its base in the inalienable rights of natural law'a conception indelibly marked by the peculiar intellectual climate of West Germany in the 1950s. Nevertheless, the similarities between Weber's early Weimar and Schmitt's late Weimar theses remain striking. For more on this controversy, see Magalhães (2016).

13 Emphasis added.
} 
first and foremost as a 'class conscious bourgeois,' to quote the self-definition he once confided in a letter to Michels (Weber 1990: 423). It is somewhat surprising-and rather unfortunate - that recent academic debate has taken its lessons and cues predominantly from the political journalist. As I will outline next, a different reading of Weber would be much more fruitful for contemporary democratic theory.

\section{Final Remarks: Weber and Contemporary Democratic Theory}

Kalyvas (2002, 2008: ch. 1) has offered the most stimulating interpretation of Weberian charisma in recent years. This left-radical political theorist proposes a Gramscian reconstruction of Weber's sociological writings, which accentuates the collective dimension of hegemonic struggles over the symbolic foundations of power. Kalyvas's approach has the undeniable merits of focusing on the theoretically more fertile portions of Weber's thinking on charisma-the texts on the sociology of religion and domination, as opposed to the later political writings-and creatively elaborating on their underdeveloped aspects. However, his strict opposition of an earlier, yet untapped collective version of Weberian charisma to a later, less promising individualistic/personalistic version misses one fundamental insight of Weber's, namely the insight into the ambivalent interplay between the collective and the personal in all instances of major social and political transformation.

In my view, reading Weber on charisma invites democratic theorists to confront head-on the challenging realization that the formation of new collective subjectivities-and, ergo, of transformative democratic identities-requires a degree of personalized leadership and authority. This realization is challenging in (at least) three different senses. First, it implies that democracy, despite its fundamental egalitarianism, cannot completely do away with forms of authority that rely on a normative distinction between leaders and followers and assign to the former an indispensable innovative role. Second, it suggests that modern democracies, in order to overcome the impasses of institutional petrification and cyclical crises of representation, must hark back to a distinctly unmodern type of authority, which paradoxically provides them with a future-oriented perspective. Finally, it intimates that a transformative democratic politics always runs the risk of turning against the democratic achievements of the rational-legal status quo it challenges-its nature being highly volatile and its outcomes unpredictable.

To be sure, some contemporary political thinkers have grasped and pondered upon these challenges without reading Weber. Ernesto Laclau, the foremost theorist of left populism, has approached them through an interpretation of Freud's social psychology. The major contribution of
Freud's perspective, according to Laclau, is that it allows one to conceptualize the formation of collective subjectivities as taking place in a continuum, whose limits are, on the one side, the unachievable 'promise of fullness contained in the notion of an entirely self-determined social whole' and, on the other side, the equally impossible total libidinal identification with 'the purely narcissistic leader' (Laclau 2005a: 35, 58). ${ }^{14}$ The Argentinian thinker thus acknowledges that authoritarian leadership is an inherent risk of a transformative democratic —or, in his terms, populist—politics. It is a risk worth taking, nonetheless, to play 'that exhilarating game that we call politics' (Laclau 2005b: 49).

Benjamín Arditi, another scholar of populism, turns to Derrida's (1993) notion of spectrality, which oscillates between 'a visitation and a more threatening haunting' (Arditi 2004: 141), to explore the same terrain of ambiguity and undecidability at the heart of democracy. For him, populist politics thrives on an indispensable redemptive promise of collective emancipation, which cannot be satisfied with the limits imposed by any given institutional incarnation of democracy, while at the same time constantly threatening to 'morph into democracy's own nemesis' (Arditi 2004: 143), i.e. into authoritarian rule. Reading Weber could, I believe, supply these explorations with a sharper sociological insight and a more robust - in its very ambivalence-theory of modernity. More generally, indeed, the bourgeoning literature on populism would have much to gain from establishing a closer dialogue with elite theory, especially in its Weberian variant.

However, the contemporary theorist whose work ties in more closely with Weber's thinking on charisma and the enigma of political innovation is Claude Lefort and his idea of democratic indeterminacy. Lefort was not aware of Weber's theory of charisma-for him Weber was strictly the theoretician of bureaucracy (see Lefort 1986: 89ff.)—but he took from Machiavelli a key insight of the elitist tradition by arguing that the 'internal division' between rulers and ruled is a constitutive feature of democratic societies, ineffaceable from the very idea, and not just from the empirical reality, of modern democracy (Lefort 1988: 218). Such a primal division between the powerful and the powerless is what nurtures the transformative impulse that pits the popular "underdog" against the institutional status quo, as Laclau would have it. Yet, as Lefort's keen analysis of the entanglement of modern democracy and totalitarianism shows, it also nurtures a contrary impulse. Indeed, the belief in the democratic 'movement which tends to actualize the image of the people' - a belief that is not 'a sign of pure illusion (Lefort 1988: 232)—harbours within itself the

\footnotetext{
${ }^{14}$ Emphasis in the original. For a compelling comparative study of Weber and Freud on the nature of authority, see McIntosh (1970).
} 
menace of leading to the 'representation of a homogenous and transparent society, of a People-as-One' (Lefort 1988: 13), ultimately incarnated by a totalitarian leader. To resist the return of what Lefort (1988: 14) calls 'the image of the body,' a counter-movement has to oppose it constantly 'by the reference to power as an empty place and by the experience of social division' (Lefort 1988: 232). Democracy, thus, oscillates between the unfulfillable promise of collective emancipation and the need to prevent such a promise from succumbing to a division-denying authoritarian/totalitarian closure. This fundamental ambiguity has been interpreted as a weakness of Lefort's democratic theory (see Gerçek 2020). For me, on the contrary, it constitutes its greatest strength - a strength which shares Weber's insight into the fugitive nature of political transformation.

Weber's writings on charisma as 'the specifically creative revolutionary force of history' confront their readers with the fragility and intrinsic ambivalence of all major political achievements. In a way, therefore, they nurture a sense of disillusionment at the same time as they generate insight. It is not surprising, for instance, that András Körösényi became more pessimistic about leader democracy when he turned more Weberian. Reading Weber, indeed, made him realize that certain 'authoritarian traits... are endogenous to democracy' (Körösényi 2019: 296). But while both democratic revolution and plebiscitary leadership are bound to end in disillusion and fail to deliver on their promises, their innovative potential is not the same. Plebiscitary leadership, as other students of Orbán's Hungary have argued, contributes to-and is a sign of - a simulacrum of democracy that is transformational in style and rhetoric only (Lengyel and Ilonszki 2012). By contrast, authentic democratic revolutions, such as those that swept across Eastern Europe in 1989, truly extend 'the boundaries of the possible and the thinkable' (Lefort 1988: 179), irrespective of the inescapably insufficient forms into which they crystallize.

Funding Open access funding provided by University of Helsinki including Helsinki University Central Hospital. This article was funded by Academy of Finland (Grand No. 312430).

Open Access This article is licensed under a Creative Commons Attribution 4.0 International License, which permits use, sharing, adaptation, distribution and reproduction in any medium or format, as long as you give appropriate credit to the original author(s) and the source, provide a link to the Creative Commons licence, and indicate if changes were made. The images or other third party material in this article are included in the article's Creative Commons licence, unless indicated otherwise in a credit line to the material. If material is not included in the article's Creative Commons licence and your intended use is not permitted by statutory regulation or exceeds the permitted use, you will need to obtain permission directly from the copyright holder. To view a copy of this licence, visit http://creativecommons.org/licenses/by/4.0/.

\section{References}

Arditi B (2004) Populism as a spectre of democracy: a response to Canovan. Political Studies 52:135-143

Derrida J (1993) Spectres de Marx. Galilée, Paris

Gerçek SE (2020) From body to flesh: Lefort, Merleau-Ponty, and democratic indeterminacy. Eur J Polit Theo 19(4):571-592

Green JE (2010a) The eyes of the people: Democracy in an age of spectatorship. Oxford University Press, New York

Green JE (2010b) Three theses on Schumpeter: response to Mackie. Political Theory 38(2):268-275

Hanke E (2001) Max Webers „Herrschaftssoziologie“. Eine werkgeschichtliche Studie. In: Hanke E, Mommsen WJ (eds) Max Webers Herrschaftssoziologie. Studien zur Entstehung und Wirkung. Mohr Siebeck, Tübingen: 19-46

Held D (2006) Models of democracy [1987], 3rd edn. Cambridge, Polity

Kalyvas A (2002) Charismatic politics and the symbolic foundations of power in Max Weber. New German Critique 85:67-103

Kalyvas A (2008) Democracy and the politics of the extraordinary: Max Weber, Carl Schmitt, and Hannah Arendt. Cambridge University Press, New York

Körösényi A (2005) Political representation in leader democracy. Gov Oppos 40(3):358-378

Körösényi A (2009) Beyond the happy consensus about democratic elitism. Comp Sociol 8(3):364-382

Körösényi A (2019) The theory and practice of plebiscitary leadership: Weber and the Orbán regime. East European Politics and Societies: and Cultures 33(2):280-301

Körösényi A, Illés G, Gyulai A (2020) The Orbán regime: Plebiscitary leader democracy in the making. Routledge, Abingdon

Laclau E (2005a) On populist reason. Verso, London

Laclau E (2005b) Populism: What's in a name? In: Panizza F (ed) Populism and the mirror of democracy. Verso, London, pp 32-49

Lefort C (1988) Democracy and political theory, trans. Minneapolis, University of Minnesota Press, D Macey

Lefort C (1986) The political forms of modern society: Bureaucracy, democracy, totalitarianism, ed. JB Thompson. Cambridge MA, MIT Press

Lengyel G, Ilonszki G (2012) Simulated democracy and pseudo-transformational leadership in Hungary. Historical Social Research / Historische Sozialforschung 37(1):107-126

Mackie G (2009) Schumpeter's leadership democracy. Political Theory 37(1):128-153

Magalhães PT (2016) A contingent affinity: Max Weber, Carl Schmitt, and the challenge of modern politics. J Hist Ideas 77(2):283-304

Magalhães PT (2021) The legitimacy of modern democracy: A study on the political thought of Max Weber, Carl Schmitt and Hans Kelsen. New York, Routledge

McIntosh D (1970) Weber and Freud: On the nature and sources of authority. Am Sociol Rev 35(5):901-911

Michels R (1911) Zur Soziologie des Parteiwesens in der modernen Demokratie. Untersuchungen über die oligarchischen Tendenzen des Gruppenlebens, Werner Klinkhardt, Leipzig

Mommsen WJ (1974a) Max Weber. Gesellschaft. Politik und Geschichte, Suhrkamp, Frankfurt

Mommsen WJ (1977) Max Weber as a critic of Marxism. The Canadian Journal of Sociology / Cahiers Canadiens De Sociologie 2(4):373-398

Mommsen WJ (1984) Max Weber and German politics, 1890-1920 [1959], trans. The University of Chicago Press, Chicago, MS Steinberg

Mommsen WJ (1989) The political and social theory of Max Weber: Collected essays. Polity, Cambridge 
Mommsen WJ (1974b) Max Weber und die deutsche Politik, 18901920 [1959], 2nd ex. edn. Mohr Siebeck, Tübingen

Nye RA (1977) The anti-democratic sources of elite theory: Pareto, Mosca, Michels. Sage, London

Pakulski J, Körösényi A (2012) Toward leader democracy. Anthem, London

Palonen K (2002) Eine Lobrede für Politiker. Ein Kommentar zu Max Webers „Politik als Beruf“. Springer, Wiesbaden

Peukert DJK (1989) Max Webers Diagnose der Moderne. Vandenhoeck \& Ruprecht, Göttingen

Radkau J (2013) Max Weber. Die Leidenschaft des Denkens. Carl Hanser, Munich

Scaff LA (1981) Max weber and robert michels. Am J Sociol 86(6):1269-1286

Scheuerman WE (2020) The end of law: Carl Schmitt in the twentyfirst century [1999], 2nd edn. Rowman \& Littlefield, London

Schluchter W (1981) The rise of Western rationalism: Max Weber's developmental history, trans. University of California Press, Berkeley, G Roth

Scott A (2018) (Plebiscitary) leader democracy: the return of an illusion? Thesis Eleven 148(1):3-20
Sohm R (1892) Kirchenrecht. Duncker \& Humblot, Leipzig

Weber M (1946) From Max Weber: Essays in sociology, trans, and. Oxford University Press, New York, HH Gerth and CW Mills

Weber M (1994) Political Writings. Cambridge University Press, Cambridge

Weber M (1978) Economy and Society [1921-1922], ed. G Roth and C Wittich. University of California Press, Berkeley

Weber M (1990) Gesamtausgabe, vol. II/5, ed. MR Lepsius and WJ Mommsen. Mohr Siebeck, Tübingen

Weber M (1992) The Protestant ethic and the spirit of capitalism [1904-1905], trans. T Parsons. Routledge, London

Weber M (2005) Gesamtausgabe, vol. I/22-4, ed. E Hanke. Mohr Siebeck, Tübingen

Weber M (2008) Gesamtausgabe, vol. II/9, ed. G Krumeich and MR Lepsius. Mohr Siebeck, Tübingen

Publisher's Note Springer Nature remains neutral with regard to jurisdictional claims in published maps and institutional affiliations. 